Revista de Metalurgia 51(1)

January-March 2015, e038

ISSN-L: 0034-8570

doi: http://dx.doi.org/10.3989/revmetalm.038

\title{
Investigation of mechanical and structural characteristics of platinum and palladium at high temperatures
}

\author{
Biserka T. Trumića ${ }^{a}$, Lidija J. Gomidželovića ${ }^{\natural}$, Saša R. Marjanovićb ${ }^{b}$ Vesna R. Krstića \\ ${ }^{a}$ Mining and Metallurgy Institute Bor, Zeleni bulevar 35, 19210 Bor, Serbia \\ ${ }^{b}$ University of Belgrade, Technical Faculty, VJ 12, 19210 Bor, Serbia \\ Corresponding author: lgomidzelovic@yahoo.com
}

Submitted: 26 August 2014; Accepted: 28 January 2015; Available On-line: 25 F ebruary 2015

\begin{abstract}
In order to broaden future application of products based on platinum and palladium a comparative analysis of their high-temperature mechanical properties was performed. Platinum and palladium are of great importance and are widely used in chemical industry, electronics, for making laboratory dishes, to name a few. Mechanical properties of pure metals, such as: tensile strength, creep rate and rupture time were investigated using universal testing machine for tensile testing of materials. Microstructure of samples was investigated by optical microscopy. Based on obtained results it can be concluded that the platinum, compared to palladium, is superior for high-temperature applications.
\end{abstract}

KEYWORDS: Annealing; Creep; Deformation; Metals; Tensile test

Citation / Cómo citar este artículo: Trumić, B.T., Gomidželović, L.J., Marjanović, S.R., Krstić, V.R. (2015) “Investigation of mechanical and structural characteristics of platinum and palladium at high temperatures". Rev. Metal. 51(1): $\mathrm{e} 038$. doi: http://dx.doi.org/10.3989/revmetalm.038.

RESUMEN: Estudio de las características mecánicas y estructurales del platino y paladio a altas temperaturas. Se realiza un estudio comparativo de las propiedades mecánicas a alta temperatura del platino y paladio, con el fin de ampliar las aplicaciones de los productos basados en estos metales. El platino y el paladio son de gran importancia y se utilizan ampliamente en la industria química, electrónica y para la fabricación de placas de laboratorio, entre otras aplicaciones. Se estudiaron las siguientes propiedades mecánicas de los metales puros: resistencia a la tracción, velocidad de fluencia y tiempo de rotura bajo condiciones de fluencia. Para esas investigaciones se utilizó una máquina universal de ensayos para realizar los ensayos de tracción. La micro-estructura fue investigada por microscopía óptica. Basándose en los resultados obtenidos, se puede concluir que el platino, en comparación con el paladio, presenta mejores prestaciones para aplicaciones a alta temperatura.

PALABRAS CLAVE: Deformación; Ensayo de tracción; Fluencia; Metales; Recocido

Copyright: (C) 2015 CSIC. This is an open-access article distributed under the terms of the Creative Commons Attribution-Non Commercial (by-nc) Spain 3.0 License.

\section{INTRODUCTION}

The interest in platinum and platinum alloys increases constantly, because the new areas of application are continuously discovered (Gavin, 2010). Today, platinum alloys, due to their characteristics such as high strength, good workability and mostly corrosion resistance at high temperatures, are present in different areas such as production of glass (Preston, 1960; Fischer, 1992) and nitrogen fertilizers (Ning et al., 1996; Yuantao and Zhengfen, 1999; Trumić et al., 2009), production of thermocouples ( Wu and Liu, 1997), production of automotive catalysts (Funabiki et al., 1991), jewelry (Biggs et al., 2005; Wright, 2002) 
and sensors (González-López et al., 2010). Recently, glucose sensors based on nanoparticles of platinum alloys with $\mathrm{Ru}, \mathrm{Pd}$ and $\mathrm{Au}$, on the carrier of carbon, have been developed (Xiao et al., 2009).

\subsection{Platinum}

The influence of cold deformation and annealing temperature on mechanical properties of platinum (samples with purity $99.5 \%, 99.9 \%$ and $99.99 \%$ ) have been studied by Trumić et al. (2010) while Loginov et al. (2007) investigated rheological properties of $99.93 \mathrm{wt} \% \mathrm{Pt}$. It was found that the destruction of $99.5 \%$ pure Pt sample occurs at the annealing temperature of $650-680{ }^{\circ} \mathrm{C}$. Samples of higher purity, with increasing annealing time, were maintaining mechanical properties. The deformation degree had almost no effect on recrystallization temperature of different purity platinum. Temperature dependence of thermodynamic and mechanical properties of six fcc transition metals ( $\mathrm{Ni}, \mathrm{Cu}, \mathrm{Ag}, \mathrm{Au}, \mathrm{Pt}, \mathrm{Rh}$ ) were examined using Molecular Dynamics (MD) simulations by Cagin et al. (1999). Comparative analysis of high temperature strength of platinum and its binary alloys with low content of alloying element was done by Trumić et al. (2012). Considering that platinum is an active component of automotive three-way catalysts, Singh et al. (2008) investigated oxidation of carbon monoxide over $\mathrm{Pt} / \mathrm{Al}_{2} \mathrm{O}_{3}$. Kim et al. (2011) examined propane combustion over $\mathrm{Pt}$ catalysts supported on various zeolites.

\subsection{Palladium}

Different ways of production of palladium nanoparticles production (Redon et al., 2011; Desforges et al., 2005), as well as palladium nanowires and nanorods (Bliznakov et al., 2011) have been investigated. Ohm and Hill (2010) examined thermoelectric behavior of palladium, and Kordas et al. (2000) studied Pd thin film deposition on polymers from liquid precursors. Edwards and Hutchings (2008) wrote about recent progress in direct synthesis of hydrogen peroxide using supported palladium and gold-palladium alloy catalysts. Anodic passivation of palladium in alkaline medium was studied by means of different electrochemical techniques (García-Ochoa and Genescá, 2000).

The aim of this study is to investigate mechanical properties and structure of platinum and palladium at high temperatures.

\section{MATERIALS AND METHODS}

All experimental examinations which results are presented in this paper were performed on platinum samples of $99.95 \%$ purity and palladium $99.5 \%$ purity.

Platinum and palladium for preparation of all samples originate from production of electrolytic copper RTB group, Serbia, obtained as by-products, technical grade. With additional refinement at Institute of Mining and Metallurgy (Bor, Serbia) purity required for sample preparation was achieved. Impurities in samples were characteristic for raw material of Bor deposits: $\mathrm{Pd}, \mathrm{Ag}, \mathrm{Au}, \mathrm{Bi}, \mathrm{Sb}, \mathrm{As}, \mathrm{Cu}$.

Melting of samples was carried out in a vacuum middle frequency induction furnace. Annealing of samples was carried out in an electro resistant furnace type LP08. For determination of hightemperature tensile strength of pure platinum and palladium in the temperature range $1100-1400{ }^{\circ} \mathrm{C}$, samples of $1.3 \mathrm{~mm}$ in diameter and $50 \mathrm{~mm}$ long were used. Before testing, the samples were annealed at $1300{ }^{\circ} \mathrm{C}$ for 3 hours. Deformation rate in tests was $6 \mathrm{~mm} \mathrm{~min}^{-1}$. For mechanical properties testing of the samples at high temperatures, a universal device for tensile testing of materials up to $1500{ }^{\circ} \mathrm{C}$, by manufacturer Karl Frank, type 81221, was used. For testing time dependant strength and elongation at high temperatures, "Mayes" MK 2 TC/10 unit, was used. Chemical analysis of samples material was performed on atomic absorption spectrophotometer. Structure of the samples was examined using an optical microscope.

\section{RESULTS AND DISSCUSION}

In order to find new possibilities of platinum and palladium use, their mechanical properties at high temperatures were examined.

Dependence of a short time tensile strength $\left(\mathrm{R}_{100}\right)$ from temperature, for pure platinum and palladium are shown in Figure 1. Dependence of tensile high temperature strength (UTS) for pure $\mathrm{Pt}$ and $\mathrm{Pd}$ from temperature, in the temperature range $900-1200{ }^{\circ} \mathrm{C}$, are shown in Figure 2.

From Figures 1 and 2, it can be concluded that short time tensile strength and tensile hightemperature strength of platinum have higher values

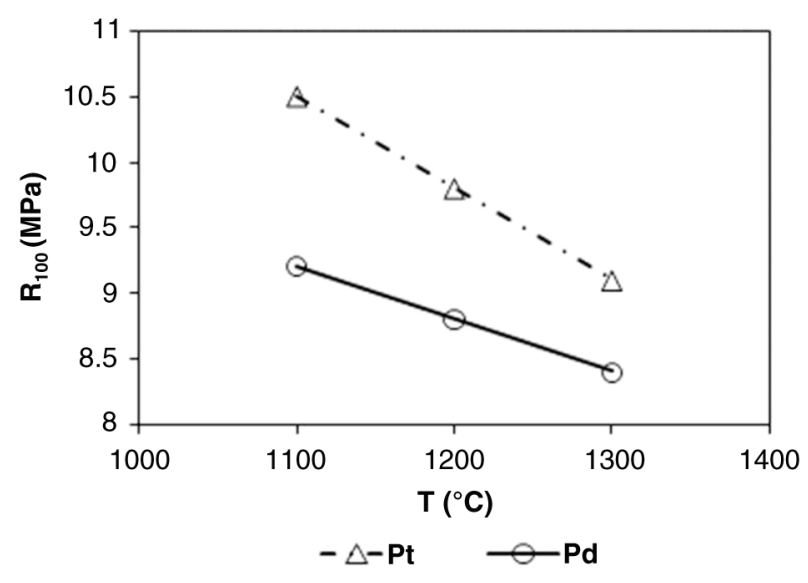

FiguRE 1. Dependence of short time tensile strength $\left(\mathrm{R}_{100}\right) \mathrm{Pt}$ and $\mathrm{Pd}$ on temperature. 


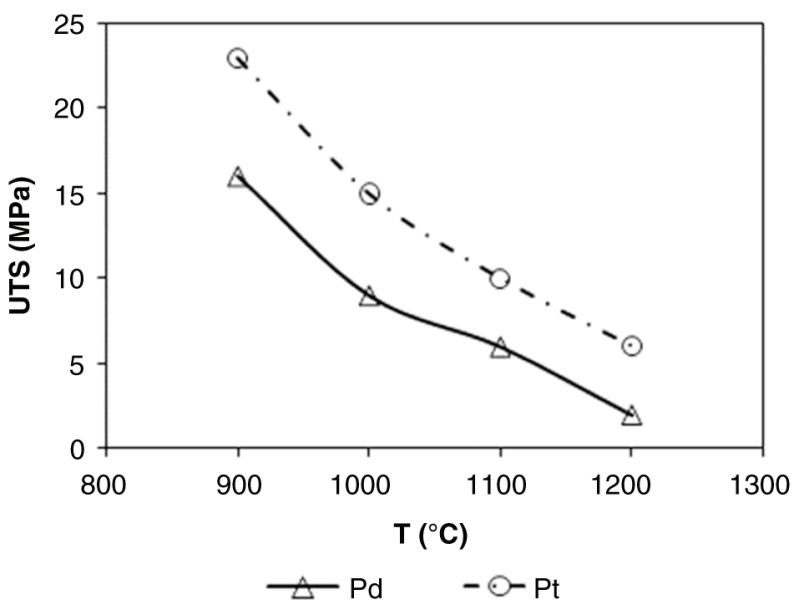

Figure 2. The dependence of tensile high temperature strength (UTS) Pt and Pd on temperature.

compared to the same mechanical properties of pure palladium. In temperature range $900-1300{ }^{\circ} \mathrm{C}$, with temperature increase these mechanical properties decrease for both, platinum and palladium.

Test results of dependence of rupture time (t) of platinum and palladium in temperature range $1200-1400{ }^{\circ} \mathrm{C}$, at a stress of $5 \mathrm{MPa}$, are shown in Figure 3. Values of rupture time of platinum and palladium in the temperature range $1200-1400{ }^{\circ} \mathrm{C}$, at a stress of $5 \mathrm{MPa}$, showed significant decrease with increasing temperature, while values for platinum were significantly higher compared to that of palladium.

Test results of creep rate $(\dot{\varepsilon})$ of platinum and palladium at 1200 and $1300^{\circ} \mathrm{C}$, at a stress of $5 \mathrm{MPa}$, are shown in Table 1. Creep speed of platinum and palladium in temperature range $1200-1300{ }^{\circ} \mathrm{C}$, at a stress of $5 \mathrm{MPa}$, increases with increasing temperature,

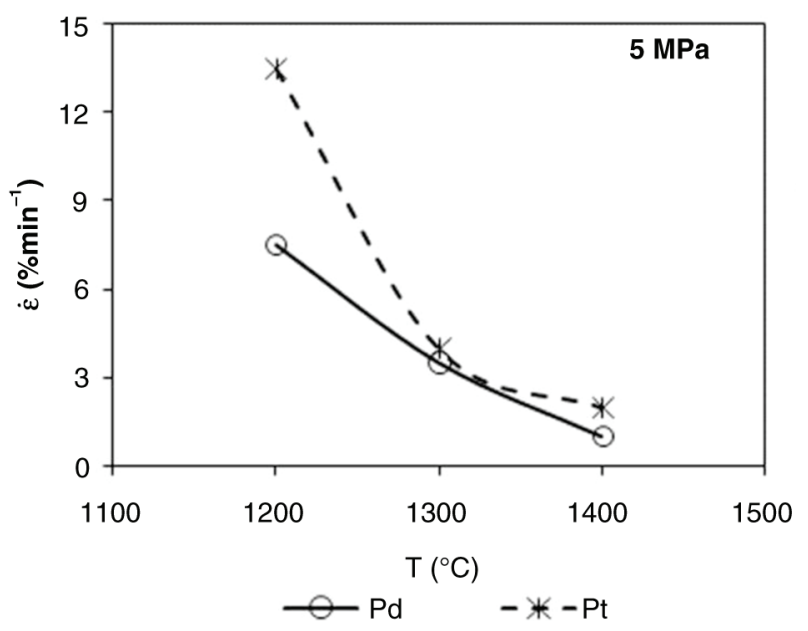

Figure 3. The dependence of the Pt and Pd rupture time from temperature, at a stress of $5 \mathrm{MPa}$.
Table 1. Creep rate values for Pt and Pd at 1200 and $1300{ }^{\circ} \mathrm{C}$, at a stress of $5 \mathrm{Mpa}$

\begin{tabular}{lcc}
\hline $\mathbf{T}\left({ }^{\circ} \mathbf{C}\right)$ & $\dot{\varepsilon}_{\mathbf{P t}}\left(\% \mathbf{~ m i n}^{-1}\right)$ & $\dot{\varepsilon}_{\mathrm{Pd}}\left(\% \mathbf{~ m i n}^{-1}\right)$ \\
\hline 1200 & 0.2 & 0 \\
1300 & 0.5 & 0.05 \\
\hline
\end{tabular}

while values for platinum are significantly higher than values of creep rate for palladium.

It is characteristic for palladium that in the investigated temperature range $\left(1200-1400{ }^{\circ} \mathrm{C}\right)$ creep resistance increases with increasing temperature, which can be explained by appearance of internal oxidation of metals or impact and effect of present impurities. The higher the creep resistance of palladium is, his rupture time in the temperature range $1200-1400^{\circ} \mathrm{C}$ is significantly shorter compared with pure platinum (Fig. 3).

A relative elongation of platinum and palladium at a stress of $5 \mathrm{MPa}$ was determined (Tables 2 and 3). From the obtained results it can be concluded that the relative elongation of platinum increases noticeably with temperature increase, while that increase in value for palladium is insignificant.

In order to investigate plasticity of palladium, fracture character at stretching in temperature range $500-1200{ }^{\circ} \mathrm{C}$ was determined. Characteristics of plasticity and fracture of the palladium samples with $2 \mathrm{~mm}$ in diameter after the high temperature stretching are given in Table 4.

For palladium, greatest plasticity was observed at $500{ }^{\circ} \mathrm{C}$. At this temperature, with prolongation of stretching time, obtained values of elongation and reduction in cross-sectional area at fracture are almost 3 times lower.

Further increasing of temperature to $700{ }^{\circ} \mathrm{C}$ reduces the plasticity of palladium. In the temperature range $900-1250{ }^{\circ} \mathrm{C}$ palladium has the lowest values of relative elongation and characteristic

TABLE 2. Relative elongation of platinum (strain $5 \mathrm{MPa}$ )

\begin{tabular}{lc}
\hline $\mathbf{T}\left({ }^{\circ} \mathbf{C}\right)$ & Elongation $(\%)$ \\
\hline 1100 & 28 \\
1400 & 55 \\
\hline
\end{tabular}

TABLE 3. Relative elongation of palladium (strain $5 \mathrm{MPa}$ )

\begin{tabular}{lc}
\hline $\mathbf{T}\left({ }^{\circ} \mathbf{C}\right)$ & Elongation $(\%)$ \\
\hline 1100 & 23 \\
1200 & 28 \\
1300 & 28 \\
\hline
\end{tabular}


TABLE 4. Plasticity and fracture characteristics of palladium samples after the high temperature tensile tests

\begin{tabular}{lclccl}
\hline $\mathbf{T}\left({ }^{\circ} \mathbf{C}\right)$ & $\sigma^{\S}(\mathbf{M P a})$ & \multicolumn{1}{c}{$\mathbf{t}^{\dagger}(\mathbf{h})$} & $\mathbf{A}^{\dagger \dagger}(\mathbf{\%})$ & $\mathbf{f}^{\ddagger}(\%)$ & \multicolumn{1}{c}{ Fracture character } \\
\hline 500 & 61 & Instant fracture & 94 & 89 & Plastic, primarily within the crystal. \\
500 & 23 & 181 & 28 & 36 & Plastic, primarily intercrystalline. \\
700 & 35 & Instant fracture & 42 & 88 & Plastic, primarily intercrystalline. \\
700 & 14 & 1416 & - & - & No fractures, intercrystalline cracks were observed on the surface. \\
900 & 8.5 & 137 & 4.4 & 2.0 & Brittle fracture, intercrystalline. \\
1250 & 1.2 & 115 & 3.5 & - & Brittle fracture, intercrystalline. \\
\hline
\end{tabular}

$\sigma^{\S}$ : Strain; $\mathrm{t}^{\dagger}$ : Time untill break; $\mathrm{A}^{\dagger \dagger}$ : Elongation; $\mathrm{f}^{\dagger}$ : Surface reduction at fracture

intercrystalline fracture, which is in agreement with literature data (Savickij et al., 1975; Ritvin, 1987).

These observed changes in plasticity of palladium in temperature range $500-700{ }^{\circ} \mathrm{C}$ can be explained by forming of solid palladium oxide (Ritvin and Medovoj, 1974), while at temperatures above $900^{\circ} \mathrm{C}$, changes are influenced by increased absorption of gases (Ritvin, 1987).

Based on the obtained results it can be concluded that palladium is much less resistant to high temperatures compared to platinum.

It was found that at a constant creep rate of $0.5 \% \mathrm{~h}^{-1}$, changes within the platinum grain occur at temperatures lower than $500-700{ }^{\circ} \mathrm{C}$, while at the same conditions for palladium, at temperatures lower than $600-800{ }^{\circ} \mathrm{C}$ (Savickij et al., 1975; Ritvin, 1987).

Our contribution to the study of creep mechanism of metals with a face centered cubic lattice, consisted in examining changes in pure platinum microstructure at a stress of $1-13 \mathrm{MPa}$ in the temperature range $1350-1400{ }^{\circ} \mathrm{C}$. The microstructure of platinum, deformed at a stress of $1 \mathrm{MPa}$ at a temperature of $1350{ }^{\circ} \mathrm{C}$ is shown in Figure 4 .

Based on the obtained microstructure of platinum, it can be concluded that as a result of hightemperature creep, straight lines and wavy traces of deformation occurs in microstructure of grains. In first case, creep traces pass through grain boundaries (Fig. 4a), in second case they weaken (Fig. 4b), while in the third case they almost don't reach grain boundaries (Fig. 4c). In Figure 4a sliding lines are visible almost on the entire grain surface, in Figure $4 b$ they are present only in grain center, while in Figure 4c they are not noticeable. It was concluded that they appear as a result of changes within grains or due to deformation processes which results in moving of grain boundaries. Dashed, wavy, and sometimes almost straight creep lines can be observed in platinum grains after high-temperature creep at $1350{ }^{\circ} \mathrm{C}$ at a stress of 5 and 13 MPa (Fig. 5).

Based on the presented results, it can be concluded that metal evaporation contributes to changes in microstructure of platinum grains at high-temperature creep. As a result of metal evaporation, there are micro geometric changes in microstructure; there is a grain boundary etching and appearance of parallel lines in grains. In terms of short-term heating (a few seconds or minutes), at moderate temperatures (below $1000{ }^{\circ} \mathrm{C}$ ) micro changes in structure develop slightly and practically don't show

a)

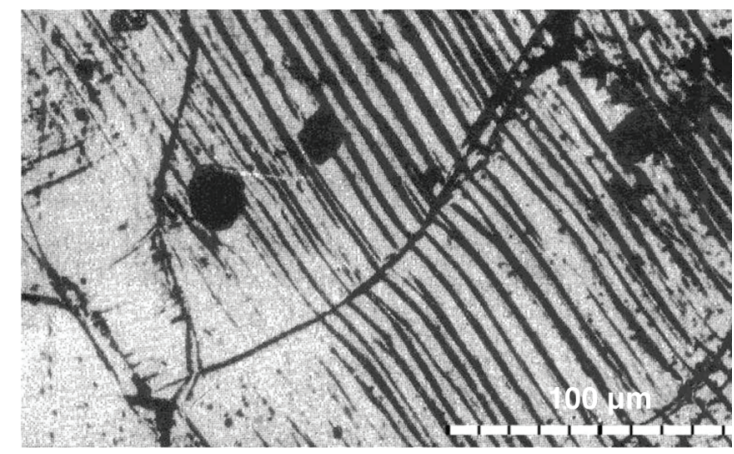

b)

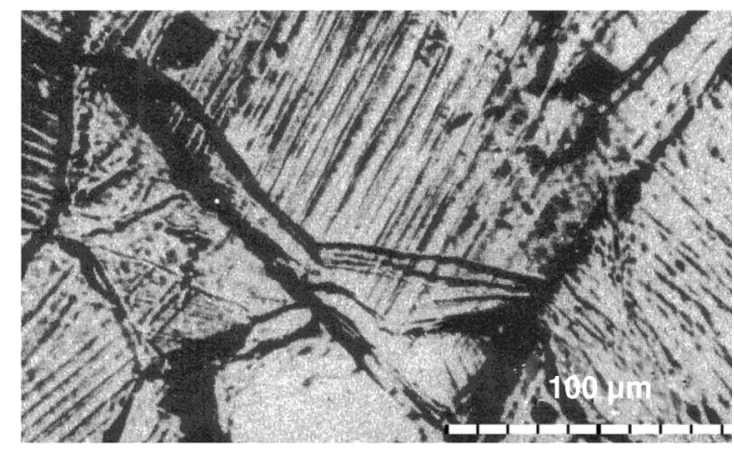

c)

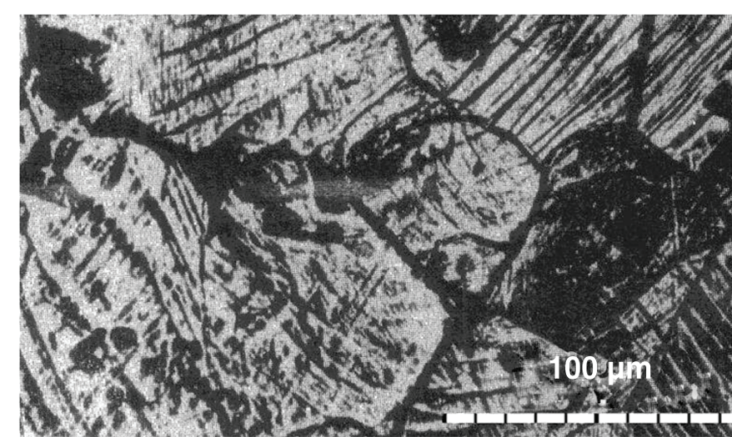

FIGURE 4. Microstructure of platinum after creep lasting 1 hour, at a stress of $1 \mathrm{MPa}$ at $1350^{\circ} \mathrm{C}(\mathrm{a}, \mathrm{b}$ and $\mathrm{c})$. 
a)

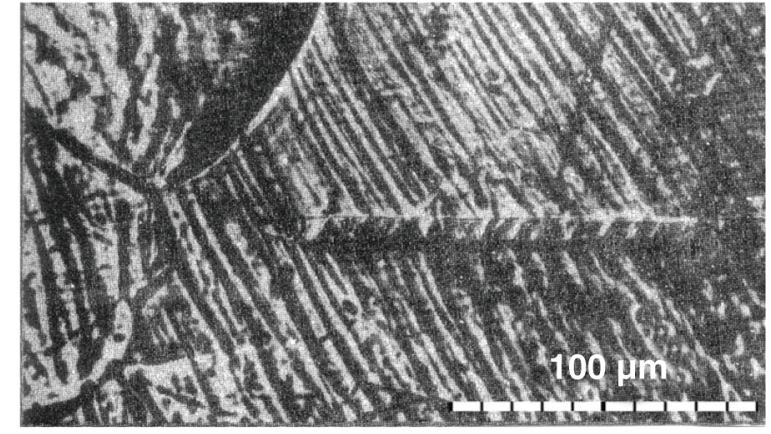

b)

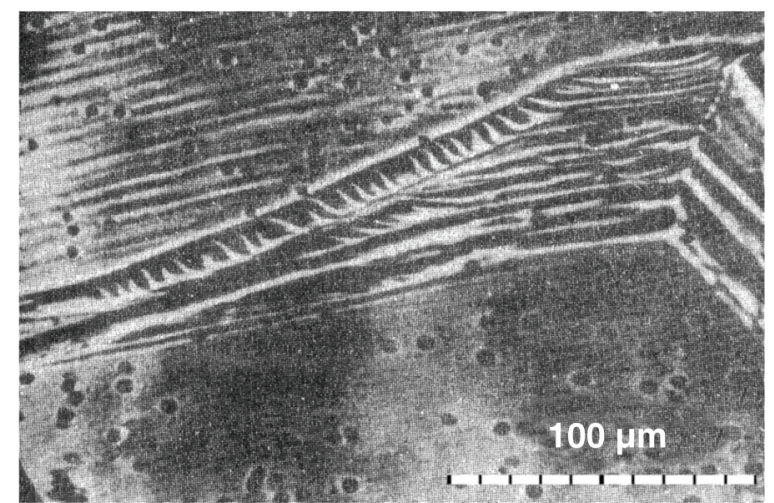

Figure 5. Platinum microstructure after creep at $1350{ }^{\circ} \mathrm{C}$ :

a) at a stress of $5 \mathrm{MPa}$ for a period of 1 hour and

b) at a stress of $13 \mathrm{MPa}$ for a period of 10 minutes.

any significant impact on high temperature stability of platinum. Prolonged heating (several hours or more) at temperatures greater than $1000{ }^{\circ} \mathrm{C}$, can lead to a pronounced structural changes, weakening of grain boundaries and accelerated destruction of metals at strain.

\section{CONCLUSIONS}

The paper presents a comparative analysis of high-temperature characteristics of pure platinum and palladium. Based on obtained results it can be concluded that:

- Values of short time tensile strength and hightemperature tensile strength of pure platinum are higher compared to the same values for palladium.

- In temperature range $900-1300{ }^{\circ} \mathrm{C}$ investigated mechanical properties decrease for both, platinum and palladium.

- Rupture time for platinum and palladium in temperature range of $1200-1400{ }^{\circ} \mathrm{C}$, at a stress of $5 \mathrm{MPa}$, decreases with increasing temperature. Values for platinum are higher in comparison to that of palladium.

- Creep rate of platinum and palladium in temperature range $1200-1300{ }^{\circ} \mathrm{C}$, at a stress of $5 \mathrm{MPa}$, increases with increasing temperature. Values for platinum are much higher compared with those for pure palladium.

- Relative elongation of platinum increases sharply in temperature range $1100-1400{ }^{\circ} \mathrm{C}$, at a stress of $5 \mathrm{MPa}$. For palladium, under same conditions, elongation increasing is negligible.

- Maximum plasticity of palladium was observed at $500{ }^{\circ} \mathrm{C}$.

- Increasing the temperature to $700{ }^{\circ} \mathrm{C}$ reduces the plasticity of palladium.

- In the temperature range $900-1250{ }^{\circ} \mathrm{C}$ palladium has the lowest values of relative elongation and typical intercrystalline fracture.

- When strained at $1 \mathrm{MPa}$ at a temperature of $1350{ }^{\circ} \mathrm{C}$ for one hour, in the microstructure of platinum grain, straight and wavy traces of deformation appear.

- After a high-temperature creep of platinum at $1350{ }^{\circ} \mathrm{C}$ at a stress of 5 and $13 \mathrm{MPa}$, dashed, wavy and very often straight creep lines in certain areas of platinum grains appear.

- At temperatures up to $1000{ }^{\circ} \mathrm{C}$, after brief heating of platinum and palladium, changes in microstructure of grains are negligible and do not significantly affect the high temperature characteristics of these metals.

- At temperatures above $1000{ }^{\circ} \mathrm{C}$, with prolonged heating of platinum and palladium, significant changes in surface structure occur, resulting in a weakening of grain boundaries and accelerated destruction of metals at strain.

- Based on overall consideration of obtained results of the high-temperature strength of platinum and palladium, it can be concluded with certainty that platinum, at temperatures over $1000{ }^{\circ} \mathrm{C}$ and under different stresses, is superior to palladium.

\section{ACKNOWLEDGMENTS}

The research results presented in this paper are the result of technological development project TR 34029 "Development of production technology of Pd catalyst-catchers to reduce losses of platinum in high temperature catalysis processes", funded by the Ministry of Education, Science and Technological Development.

\section{REFERENCES}

Biggs, T., Taylor, S.S., van der Lingen, E. (2005). The hardening of platinum alloys for potential jewellery application. Platinum Met. Rev. 49 (1), 2-15. http://dx.doi.org/ 10.1595/147106705x24409.

Bliznakov, S., Vukmirovic, M., Sutter, E., Adzic, R. (2011). Electrodeposition of palladium nanowires and nanorods on carbon nanoparticles. Maced. J. Chem. Chem. Eng. 30 (1), 19-27.

Cagin, T., Dereli, G., Uludogan, M., Tomak, M. (1999). Thermal and mechanical properties of some fcc transition metals. Phys. Rev. B: Condens. Matter. 59, 3468-3473. http:// dx.doi.org/10.1103/PhysRevB.59.3468. 
Desforges, A., Backov, R., Deleuze, H., Mondain-Monval, O. (2005). Generation of Palladium Nanoparticles within Macrocellular Polymeric Supports: Application to Heterogeneous Catalysis of the Suzuki-Miyaura Coupling Reaction. $A d v$. Funct. Mater. 15 (10), 1689-1695. http://dx.doi.org/10.1002/ adfm. 200500146.

Edwards, J.K., Hutchings, G.J. (2008). Palladium and GoldPalladium Catalysts for the Direct Synthesis of Hydrogen Peroxide. Angew. Chem. Int. Edit. 47 (48), 9192-9198. http://dx.doi.org/10.1002/anie.200802818.

Fischer, B. (1992). Reduction of Platinum Corrosion in Molten Glass. Platinum Met. Rev. 36 (1), 14-25.

Funabiki, M., Yamada, T., Kayano, K. (1991). Auto exhaust catalysts. Catal. Today 10 (1), 33-43. http://dx.doi.org/ 10.1016/0920-5861(91)80072-H

Gavin, H. (2010). Platinum group metals research froma global perspective. Platinum Met. Rev. 54 (3), 166-171. http:// dx.doi.org/10.1595/147106710x500125.

García-Ochoa E.M., Genescá J. (2000). EIS and electrochemical noise study of anodic passivation of palladium in alkaline medium. Rev. Metal. 36, 3-12. http://dx.doi.org/10.3989/ revmetalm.2000.v36.i1.492.

González-López S., Romero-Serrano A., Vargas-García R. Zeifert B., Cruz-Ramírez A. (2010). Analysis of the deoxidation process of copper with manganese using a platinum electrode-based sensor prepared by MOCVD. Rev. Metal. 46 (3), 219-226. http://dx.doi.org/10.3989/revmetalm.0927.

Kim, K.B., Kim, Y.H., Song, K.S., Park, E.D. (2011). Propane combustion over Pt catalysts supported on zeolites. Rev. Adv. Mater. Sci. 28 (1), 35-39.

Kordas K., Nánai L., Bali K., Stepan K., Vajtai R., George T.F., Leppävuori, S. (2000) Palladium thin film deposition from liquid precursors on polymers by projected excimer beams. Appl. Surf. Sci. 168 (1-4), 66-70. http://dx.doi.org/10.1016/ S0169-4332(00)00592-4.

Loginov, Yu.N., Yermakov, A.V., Grohovskaya, L.G., Studenok, G.I. (2007). Annealing Characteristics and Strain Resistance of $99.93 \mathrm{wt} . \%$ Platinum. Platinum Met. Rev. 51 (4), 178-184. http://dx.doi.org/10.1595/147106707x237708.

Ning, Y., Yang, Z., Zhao, H. (1996). Platinum recovery by palladium alloy catchment gauzes in nitric acid plants. Platinum Met. Rev. 4 (2), 80-87.

Ohm, W.S., Hill, K.D. (2010). A Mechanism for the OxidationRelated Influence on the Thermoelectric Behavior of Palladium. Int. J. Thermophys. 31 (8-9), 1402-1416. http:// dx.doi.org/10.1007/s10765-010-0748-2.

Preston, E. (1960). Platinum in the glass industry. Platinum Met. Rev. 4, 48-55.
Ritvin, E.I., Medovoj, L.A. (1974). Vlianie fiziko-himicheskoj sledi na zharoprochnost merallicheskih materialov. Nauka, Moskva.

Ritvin, E.I. (1987). Zharoprochnost platinovih splavov. Metalurgija, Moskva, Russian

Redon, R., Rendon-Lara, S.K., Fernández-Osorio, A.L., Ugalde-Saldivar, V.M. (2011). Aerobic synthesis of palladium nanoparticles. Rev. Adv. Mater. Sci. 27, 31-42.

Savickij, E.M., Poljakova, V.P., Gorina, N.B., Roshan, N.R. (1975), Metalovedenie platinovih metalov. Metalurgija, Moskva, Russian.

Singh, J., Alayon, E.M.C., Tromp, M., Safonova, O.V., Glatzel, P., Nachtegaal, M., Frahm, R., van Bokhoven, J.A. (2008). Generating Highly Active Partially Oxidized Platinum during Oxidation of Carbon Monoxide over $\mathrm{Pt} / \mathrm{Al}_{2} \mathrm{O}_{3}$ : In Situ, Time-Resolved, and High-Energy-Resolution X-Ray Absorption Spectroscopy. Angew. Chem. Int. Edit. 47 (48), 9260-9264. http://dx.doi.org/10.1002/anie. 200803427.

Trumić, B., Stanković, D., Trujić, V. (2009). Examining the surfaces in used platinum catalysts. J. Min. Metall. Sect. B. 45 (1), 79-87. http://dx.doi.org/10.2298/JMMB0901079T.

Trumić, B., Stanković, D., Ivanović, A. (2010). The impact of cold deformatioon, annealing temperatures and chemical assays on the mechanical properties of platinum. J. Min. Metall. Sect. B. 46 (1), 51-57. http://dx.doi.org/10.2298/ JMMB1001051T.

Trumić, B., Gomidželović, L., Trujić, V., Krstić, V., Stanković, D. (2012). Comparative analysis of high temperature strength of platinum and its binary alloys with low content of alloying element. Hem. Ind. 66 (3), 395-401. http://dx.doi. org/10.2298/HEMIND110718106T

Wright, J.C. (2002). Jewellery-Related Properties of Platinum: Low Thermal Diffusivity Permits Use of Laser Welding for Jewellery Manufacture. Platinum Met. Rev. 46 (2), 66-72.

Wu, B., Liu, G. (1997). Platinum: Platinum-rhodium thermocouple Wire. Platinum Met. Rev. 41, 81-85.

Xiao, F., Zhao, F., Mei, D., Mo, Z., Zeng, B. (2009). Nonenzymatic glucose sensor based on ultrasonic-electrodeposition of bimetallic PtM ( $\mathrm{M}=\mathrm{Ru}, \mathrm{Pd}$ and $\mathrm{Au})$ nanoparticles on carbon nanotubes-ionic liquid composite film. Biosens. Bioelectron. 24 (12), 3481-3486. http://dx.doi.org/10.1016/j. bios.2009.04.045.

Yuantao, N., Zhengfen, Y. (1999). Platinum loss from alloy catalyst gauzes in nitric acid Plants. Platinum Met. Rev. 43 (4), 62-69. http://www.technology.matthey.com/article/ $43 / 4 / 167-167-2 /$ 